International Journal of Advanced Information Technology (IJAIT) Vol. 7, No.5, October 2017

\title{
ASCERTAINING THE INFORMATION AND COMMUNICATION TECHNOLOGY (ICT) MATURITY LEVEL Of THE BANKING SECTOR USING KOCHIKAR MODEL
}

\author{
Ejiofor C. I \& Okengwu U.A \\ Department of Computer Science, University of Port-Harcourt, Port-Harcourt. Nigeria
}

\begin{abstract}
Information and Communication Technology has indeed been the driving force in most economics of the world owing to its versatility in integrating with most national sectors. Information and Communication Technology (ICT) models have been developed with the sole aim of ascertaining the maturity level in various economic sectors from the perspective of ICT. Due to the divergent impact of ICT in the Banking sector in Nigeria; this research paper has attempted to ascertain the maturity level within the banking sector using KochiKar Model: a Knowledge-driven ICT maturity model. The dataset for analysis was obtained using structured interview approach spread across Ten (10) Nigeria banks, capturing 12 personnel's each with an overall total of 120 respondents. The ICT maturity parameter indicators show clearly that Application, Human Resource Infrastructure and Policy have varied ratio of: 65\%, 46\%, 30\% and $16 \%$, respectively while the overall maturity index was captured at 0.40 (40\%) falling into "BASIC" level within the stages of Kochikar model measurement. These results have highlighted the need in improving policies and infrastructures tremendously while applications and human resources can be expanded gradually which will overall increase the maturity index level.
\end{abstract}

\section{KEYWORDS:}

Kochikar, ICT, ICT maturity, ICT Maturity

\section{INTRODUCTION}

Information and communication Technology (ICT) has proved to be a change agent in most countries, nations and continents of the world which has bought fundamental change across world economics and societies, creating more jobs, earning more income, accessing more useful information and transformingthe world into a virtual global village (Aderemi, 2016). The ICT sector has become, the most predominant sector accounting for up to $7.5 \%$ of the Gross Domestic Product (GDP) worldwide and 3.5\% of Nigeria's GDP (Aderemi, 2006).

ICT policies have been develop with the aim of achieving clear-cut out goals on the development of national information and infrastructures, ensuring seamless interconnectivity in ICT development in Nigeria (Ekezie, 1997; Adetunji, 2006). The promotion of technological capability in local production of ICT equipment's and material such as computer and telephones are the impetus for these policies. These policies have been develop, documented, monitored and controlled by the National Information Technology Development Agency (NITDA) and integral facet of government (Adetunji, 2006).

With these polices and infrastructure in focus, there are still some notable issues militating against the total advancement of ICT in various sectors in Nigeria (Ekezie, 1997; Adetunji, 2006).

DOI : 10.5121/ijait.2017.7501 
International Journal of Advanced Information Technology (IJAIT) Vol. 7, No.5, October 2017

One of these is the limited access to information and communication Technology (ICT) infrastructures, of which service rate and charges are fundamental issues. While others issues focus on the prompt adoption of this polices in enhancing economic development within a countries viable sector. Still yet, we have massive illiteracy rate in ICT tools and high cost of accessing computers and internet and also poor implementation of government policies in various sectors (Ekezie, 1997; Adetunji, 2006).

Notable, is the banking sector where the impact of ICT has still beendivergent till date owning to: professional and well- meaning organization holding to the fact that ICT and it accommodating peripherals has helped the banking sector. Others have strongly disagreed, accusing the banking sector of fostering certain distortion aimed at replacing human capital with machine capital (Ekezie, 1997).

Measuring the level of ICT adoption in term of infrastructure, content, as well as usage within the banking sector cannot be overemphasized. Based on the aforementioned issues, it is necessary that the maturity level of ICT in the Banking sector be measured in order to identify its current profile and to defile the objectives of an improvement in the banking sectors as this will enhance strategic planning and functioning for future ICT investments.

The focal point of this paper is centered on ascertaining the ICT maturity level of Nigeria banking sector using a structured interview approach.

\section{Material AND MethodS}

This section portrays the available Information and Communication Technology (ICT) models which have been utilized in measuring or determining the ICT maturity level.

\subsection{Knowledge Management Maturity Model}

The Knowledge Management Maturity Model (K3M) is a long term roadmap spread across eight main level. The first four levels are geared towards building an internal competence in sciences, encoding, delivering and collecting knowledge. Level five through seven focuses on ripening the spirit of innovation within the company. These Levels includes: Standardized Infrastructure for Knowledge Sharing, Top-Down Quality-Assured Information Flow, Top-Down Retention Management, Organizational Learning, Organizational Knowledgebase, Process-Driven Knowledge Sharing, Continual Process Improvement and Organizational Self-Actualization (Kazimi, 2004).

\subsection{Capability Maturity Model}

Capability Maturity Model is a maturity model or framework, aimed at helping organization improve their software development life cycle processes. This model is particular in eliminating excessive project scheduling delay and cost overrun by providing appropriate structure and supports. This enables organizations to focus on a limited set of activities to steadily improve software process capability. This model is made up of initial, repeatable, defined, managed, and optimizing.

\subsection{UNESCO Model Of ICT Maturity}

UNESCO's model of ICT maturity has four different levels as stated by UNESCO (2002): emerging stage, applying stage, infusing stage and transforming stage. The emerging stage is seen as the beginning stage of ICT development which is demonstrated in the current sector. It 
involves the purchase of computing equipment and other ICT infrastructures. The applying stageaccommodatesnew understanding of the contribution of ICT that has developed past the emerging stage. The infusing stage integrating or embedding ICT across the services provided or managed by that sector and it is seen in sectors that now employ a range of computer based technologies in their laboratories, administrative offices. In the transforming stage, ICT has become an integral part of organizational development.

\subsection{Nolan's Maturity Model}

Nolan's maturity model defines the adoption of ICT into an organization or sector as a series of clearly articulated developmental stages. Nolan identified six stages. This is a general model, which describes the role of information technology (IT), and how it grows within an organization. Evolution of IT in organizations begins in an initiation stage; this is followed by expeditious spreading of IT in a contagion which closely linked with a need for control, integration of diverse technological solutions evolving gradually. This followed assiduously by administration of data which allow development without chaotic and increasing IT expenditure. With these in focus, constant ICT growth is expected (Galliers, and Sutherland, 2003).

\subsection{Cloud Maturity Model}

A Cloud maturity model is an ideal unifying program for IT because it is holistic in terms of how it can address both business and IT requirements. It encompasses everything that is currently cutting edge in terms of new IT, while also dealing with very practical issues like achieving value for money through IT outsourcing. It is made up of six levels which includes

None -the none level is seen as the none level of cloud existence.

Ad Hoc - existence of cloud computing begins to emergence.

Opportunistic - An approach has been decide upon, though not widely accepted it may be defined informally.

Systematic - The informal approach has been accepted by all parties

Managed - The operation are being measured quantitatively

Optimized - Measurement data are been used to optimize processes.

\subsection{Kochikar Model For Measuring ICT Maturity}

Kochikar model is made up of five levels; with level 1 seen as inactive in which no current use of ICT is explored in this stage. Level 2 seen as basic; at the stage the use of word processing and other desktop packages are felt. Level 3 seen as substantial; the sector integral software packages with network PCs and several applications. Level 4 seen as Web; the sector will combine software packages, networking Pcs with e-commerce enhanced by web-based services. Level 5; Knowledge oriented, the sector will have word processing and other desktop packages there will also be networking of PCs and several applications will be available, there will also be web-based services in the sector. There will also be integration, the application of ICT and using ICT tools for innovation and management of the Banking sector.

\section{RESEARCH METHODOLOGY}

The research methodology covers data collections and analysis of data. The data was collected through a structured interview approach, attuned toward the main levels of Kochikar model. The collected data was analyzed using kochikar model based on it extensiveness in defining ICT knowledge management and its well defined structure 
providing easy ofcomprehensionand accuracy of result.The Model is given at equation 1 . The model provides a formula in determining ICT maturity level.

$$
\begin{gathered}
I C T M I=\frac{(I+O+M+P)(0 \leq I, O, M, P, I C T M I \leq 1)}{4}\left(\begin{array}{l}
\sum_{l=1}^{4}\left(\frac{\sum_{k=1}^{n_{1}} I_{l k}}{n_{l}}\right) \\
4
\end{array}\right. \\
O=\frac{\sum_{l=1}^{4}\left(\frac{\sum_{k=1}^{m_{1}} o_{l k}}{m_{l}}\right)}{4} \\
M=\frac{\sum_{l=1}^{4}\left(\frac{\sum_{k=1}^{p_{1}} M_{l k}}{p_{l}}\right)}{4} \\
P=\frac{\sum_{l=1}^{4}\left(\frac{\sum_{k=1}^{q_{1}} P_{l k}}{q_{l}}\right)}{4}
\end{gathered}
$$

$\left(I_{l k}, O_{l k}, M_{l k}, P_{l k}:\right.$ indicators of stage $1 ; n_{l}, m_{l}, p_{l}, q_{l}:$ number of respective indicators of stagel).

\section{Equation 1: Kochikar model.}

The data collection was obtained from twelve (12) anonymous personals of Ten (10) banks in Nigeria. These Banks are: United Bank for Africa (UBA), First Bank, Guaranty Trust Bank, Union Bank, Zenith Bank, Fidelity Bank, Wema Bank Access Bank, Diamond Bank and Sterling Bank.

Table 1 shows the various indicators (structured questions). It gives us an analysis the respondents replied to the structured interview questions. A total of 120 personals were interviewed. It shows the number of people out of the 100 who were aware (YES) of the various indictors and those who were not aware (No). It also shows the different ICT stage of each of the indicators: Inactive, Basic, Substantial, Web- Based, and Knowledge Oriented. Simple percentage was used to arrive at what stage each of these indicators is in the Nigeria Banking sector. Since we have five stages, the percentage 100 will be divided equally, where each portion is assigned its range. 
Table 1: Analysis of Dataset

\begin{tabular}{|c|c|c|c|c|c|c|c|c|c|c|c|c|c|c|}
\hline \multirow{2}{*}{$\begin{array}{l}\text { MADN } \\
\text { FACTOES }\end{array}$} & \multirow[t]{2}{*}{ DNOICATORS } & \multirow[b]{2}{*}{$\stackrel{\square}{\curvearrowright}$} & \multirow[b]{2}{*}{$\frac{8}{2}-1-1-1-1$} & \multirow[b]{2}{*}{$\vec{k}$} & \multirow[b]{2}{*}{ 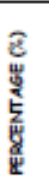 } & \multirow[b]{2}{*}{$\begin{array}{l}\text { 㟧 } \\
\text { s. } \\
\text { t. }\end{array}$} & \multicolumn{5}{|c|}{ IETMI } & \multirow[b]{2}{*}{ 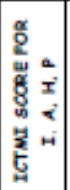 } & \multirow[b]{2}{*}{ 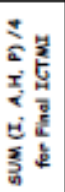 } & \multirow[b]{2}{*}{ 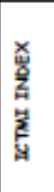 } \\
\hline & & & & & & & $\begin{array}{l}\vec{w} \\
\frac{\vec{w}}{5}\end{array}$ & $\frac{2}{\tilde{z}}$ & $\begin{array}{l}\frac{m}{w} \\
\frac{3}{5} \\
\frac{5}{5}\end{array}$ & 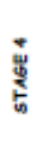 & 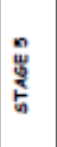 & & & \\
\hline \multirow{6}{*}{ 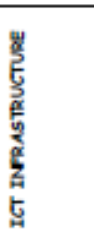 } & $\begin{array}{c}\begin{array}{c}\text { Functionsl Availabble } \\
\text { Comouters }\end{array} \\
\end{array}$ & 116 & 04 & 120 & 96.6 & 5 & \multirow[t]{6}{*}{0} & \multirow[t]{6}{*}{0} & \multirow[t]{6}{*}{0} & \multirow[t]{6}{*}{$1 / 4$} & \multirow[t]{6}{*}{$1 / 20$} & \multirow[t]{6}{*}{$6 / 20$} & \multirow[t]{24}{*}{$1.57 / 4$} & \multirow{24}{*}{$\begin{array}{l}0.40 \\
\text { B } \\
A \\
\text { S } \\
\text { I } \\
C\end{array}$} \\
\hline & Functional Fax mochine & 73 & 47 & 120 & 60.8 & 4 & & & & & & & & \\
\hline & Intermet Access & 118 & 02 & 120 & 983 & 5 & & & & & & & & \\
\hline & Security and Bechup Sof twere & 108 & II & 120 & 900 & 5 & & & & & & & & \\
\hline & Wireless LAN & 112 & 08 & 120 & 933 & 5 & & & & & & & & \\
\hline & Availebility of Website & 117 & 03 & 120 & 97.5 & 5 & & & & & & & & \\
\hline \multirow{6}{*}{ 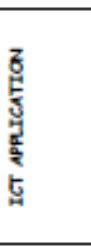 } & Licensed Softwore & 109 & II & 120 & 90.8 & 5 & \multirow[t]{6}{*}{0} & \multirow[t]{6}{*}{0} & \multirow[t]{6}{*}{$1 / 3$} & \multirow[t]{6}{*}{$1 / 4$} & \multirow[t]{6}{*}{$1 / 16$} & \multirow[t]{6}{*}{$31 / 48$} & & \\
\hline & Intermet banking Software & 104 & 16 & 120 & 86.6 & 5 & & & & & & & & \\
\hline & Available Mobile App & 109 & II & 120 & 90.8 & 5 & & & & & & & & \\
\hline & E-Marketing Softowere & 63 & 57 & 120 & 52.5 & 3 & & & & & & & & \\
\hline & e-mail/ IM Comnunication & 95 & 25 & 120 & 791 & 4 & & & & & & & & \\
\hline & $\begin{array}{c}\text { Menogenent Infformation } \\
\text { System }\end{array}$ & 101 & 19 & 120 & 841 & 5 & & & & & & & & \\
\hline \multirow{6}{*}{ 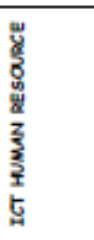 } & ICT Training & 69 & 51 & 120 & 57.5 & 3 & \multirow[t]{6}{*}{0} & 0 & $1 / 8$ & $1 / 12$ & $1 / 4$ & $22 / 48$ & & \\
\hline & IT Experts & 74 & 46 & 120 & 617 & 4 & & & & & & & & \\
\hline & Mandatory Certification & 83 & 37 & 120 & 69.2 & 4 & & & & & & & & \\
\hline & $\begin{array}{c}\text { Budget for Research } \Delta \\
\text { Development }\end{array}$ & 37 & \begin{tabular}{|l|l|}
83 & -1 \\
\end{tabular} & 120 & 40.8 & 3 & & & & & & & & \\
\hline & Mandatory IT Research & 101 & 19 & 120 & 841 & 5 & & & & & & & & \\
\hline & IT Departments & 88 & 32 & 120 & 73.3 & 4 & & & & & & & & \\
\hline & Quality Policies & 92 & 28 & 120 & 76.6 & 4 & 0 & 0 & 0 & $1 / 12$ & $1 / 12$ & $2 / 12$ & & \\
\hline & Secarity Policies & 87 & 33 & 120 & 72.5 & 4 & & & & & & & & \\
\hline , & Work policies & 100 & 20 & 120 & 83.3 & 5 & & & & & & & & \\
\hline 8 & Safety policies & 107 & 13 & 120 & 891 & 5 & & & & & & & & \\
\hline L & Privacy Policies & 113 & 07 & 120 & 941 & 5 & & & & & & & & \\
\hline & Hardwerre/Sof tmare Policies & 87 & \begin{tabular}{|l|}
33 \\
\end{tabular} & 120 & 72.5 & 4 & & & & & & & & \\
\hline
\end{tabular}

\section{ANALYSis Of RESUlT}

The results analysis and evaluation are captured from two predominant phase, parameter indictor and ICT maturity index.

\subsection{Parameter Indicator}

Table 1 captures the ICT maturity index score for infrastructure, application, human resources and policy which will be utilized in arriving at a parameter indicator.In other to achieve an appreciable scale for each of these parameter indicators under ICT maturity, these scaled values are converted into percentage for each parameter indicator. Therefore; infrastructure has a percentage value of:0.3(30\%), application has a percentage value of: $0.65(65 \%)$, human resource has a percentage value of: $0.46(46 \%)$ and policy has a percentage of value: $0.16(16 \%)$. 


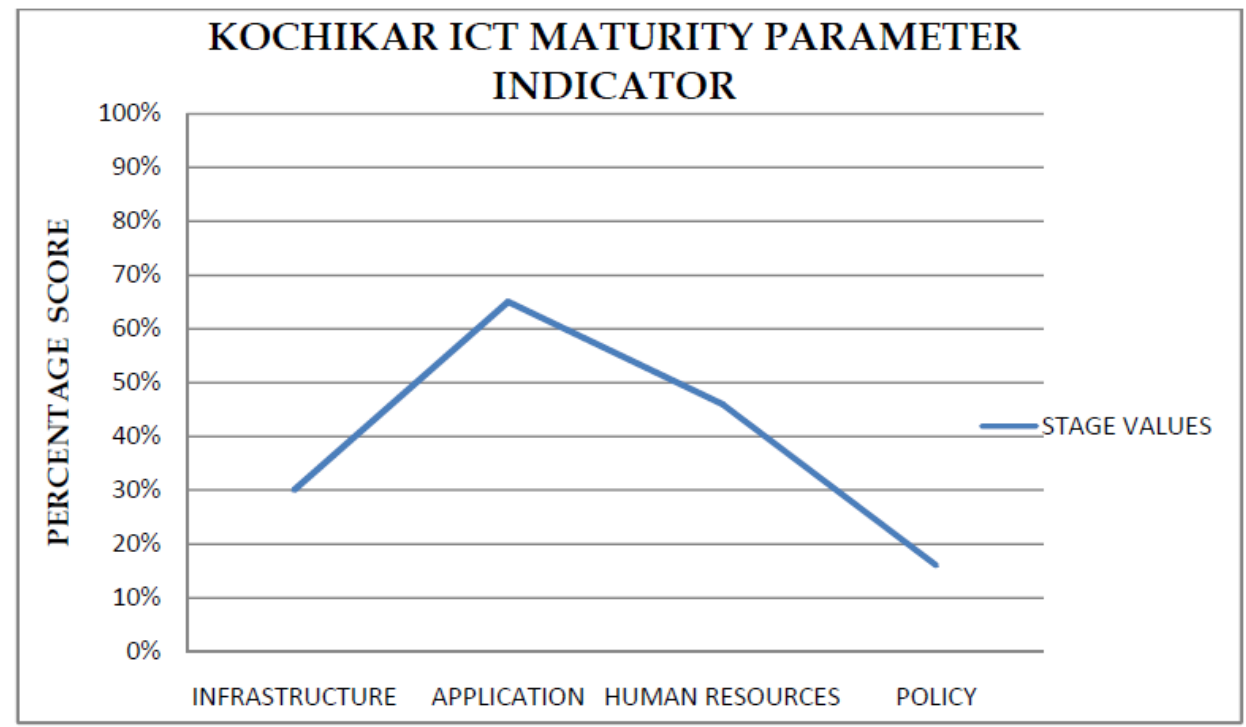

Figure 2: kochikar ICT Maturity Parameter Indicator

It is clear from the line graph of Figure 2, that the highest parameter indicator is tied to application, succeeded by human resources, then infrastructures before policy. This show clearly that the banking sector are hugely invested in application as a predominate means of attaining their ICT maturity quest with human resources closely at pal with ICT application while infrastructure and policies are still struggling.

\subsection{Information And Communication Technology Maturity Index (Ictmi)}

The ICT maturity index captures the stage of ICT maturity taking cognizant the level accepted under the Kochikar model. These levels: Inactive (0-20\%), Basic (20-40\%), Substantial (40 $60 \%)$, Web Based $(60 \%-80 \%)$ and Knowledge Oriented (80\% -100\%). The graph of Figure 3 shows the ICT Maturity Index (ICTMI) for the banking Sector using kolchikar model.

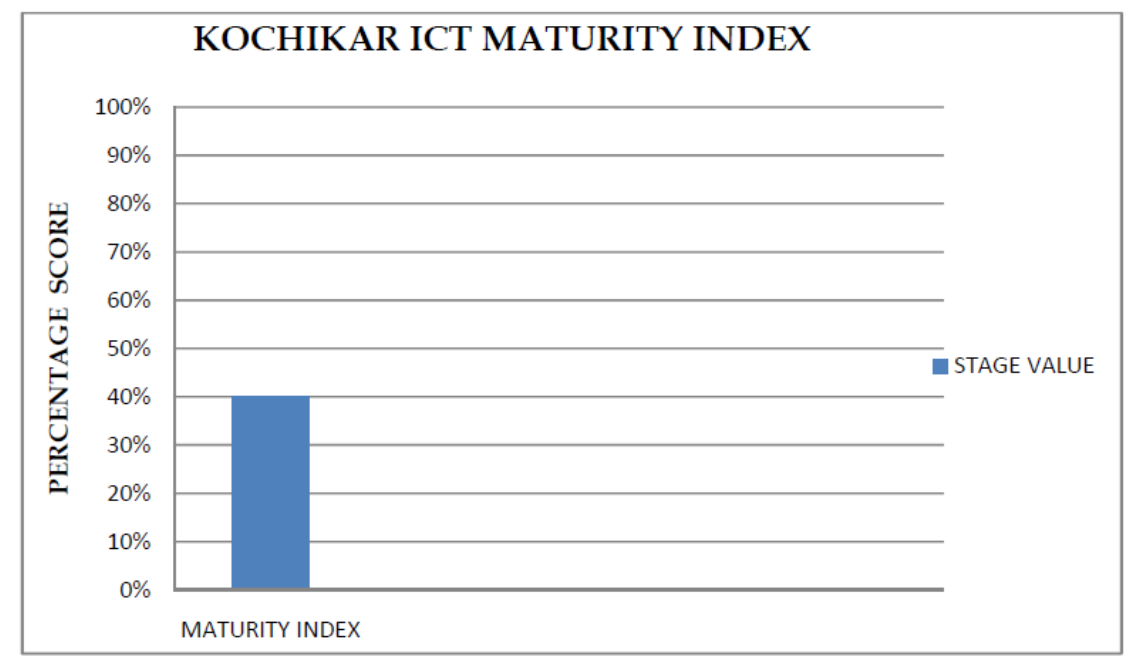

Figure 3: kochikar ICT Maturity Index 
It is clear from the line graph of Figure 3that the highest ICT maturity Index based on this research survey proffer a value of $0.4(40 \%)$. This falls within the level of Basic; highlighting the need for the banking sector to improve toward substantial, web- based and Knowledge-oriented.

\section{CONCLuSion}

This research has established the usefulness of Kochikar model in ascertaining the maturity index within Nigeria banking sector using structured interview as a data collection techniques. The dataset were analyzed using Kochikar model in ascertaining level of existences (Inactive, Basic, Substantial, Web-Based and Knowledge Oreinetd). This study has established that the banking sector has an ICT maturity index of about $0.40(40 \%)$ which shows that the sector is currently in BASIC and made evident that the infrastructure, organization software, manpower resources and policy capability of the sector needs to be improved.

\section{REFERENCES}

[1] Adetunji, O. (2006). Creating appropriate technology as a means of waste minimization in cassava end products. Retrieved from http:// www.nifst.org.

[2] Ekezie E.S.(1997)The Elements of Banking.Onitsha:Africana-Feb Publishers Ltd. Federal Republic of Nigeria Official Gazette.(1991)No. 26 Volume 78,Decree No. 24 Central Bank of Nigeria Decree and Decree No.25 Banks and other Financial Institutions Decree.Lagos:Govt Printer.

[3] Galliers, R. D., and Sutherland, A. R. (2003). "The Evolving Information Systems Strategy Information Systems Management and Strategy Formulation: Applying and Extending the Stages of Growth Concept'. Strategic Information Management: challenges and strategies in Managing Information Systems. 3rd Fed. Oxford: Butterworth-Heinemann.

[4] Kalakata \&Robbinson, M. (2001). E-Business 20 Road many Express Addition.

[5] Kazimi, J., Dasgupta,R.R. and Natarajan, G. (2004) "The rise, fall and rise of knowledge management.Available online at http:// www.zenzar.com $/$ pdfs $/ \mathrm{km} 2 . p d f$.

[6] Kochikar, V.P. (2000), The knowledge management maturity model: A staged framework for leveraging KM World, CA, USA.

[7] Kolawole,T.O., Adeigbe, K.,Hiliary, O. E. (2014), The Role of Intensive ICT Adoption and Use on Industrial Development and the Attainment of Millennium Development Goals in Nigeria, Journal of information and Knowledge and management, Vol. 4

[8] Lopez,V. (2003), An exploration of the use of information technology in college classroom.

[9] Murray J. (2011), Cloud Network Architecture and ICT- Modern Network Architecture, IT Knowledge Exchange, retrieved from http:// www.itknowledgexchange.com

[10] Nasscom,(2002). Sustainable tomorrow: Harnessing ICT Potential. Retrieved from www.nasscom.com.

[11] Nolan, R. (1973); "Managing the Computer Resources: Stage Hypothesis". Harvard Business Review 16 (4): 399-405.

[12] Nolan, R. (1979); “Managing The Crisis In Data Processing”. Harvard Business Review 57 (2): 115 126.

[13] Nwosu \& Godfred, C.(2003), Information technology Basic management, Emg and Company publisher Ltd. 
International Journal of Advanced Information Technology (IJAIT) Vol. 7, No.5, October 2017

[14] Oyelaran-Oyeyinka, B.\& Lal, K., (2004)."Sectoral Pattern of E-business Adoption in Developing Countries", Discussion Paper, DP 2004-7, 2004, UNU-INTECH, Maastricht

[15] Toluwani A. A. (2004) 'The Evolution of Nigerian Banking System, Supervison and Current challenges, retrieved online from http://www.academia.edu/3807072/T WHO (2004), "The World Health Report", retrieved from www.who.int/whr/2004/e

[16] Wilson J. (2012), “The Lancet Commissions Shaping cities for health", retrieved from press.thelancet.com/healthycities.pdf. World Bank Institute (2011); "Knowledge Innovation and Knowledge Economy Index", WB, USA.

[17] Zuppo,\& Colrain M (2015). "Defining ICT in a Boundaryless World: The Development of a Working Hierarchy" (PDF). International Journal of Managing Information Technology (IJMIT). p. 19. 